\title{
Comparison of Soil Quality Improvement under Different Fallow Types on Dystric Nitosols Derived from Sand Stone in South Western Nigeria
}

\author{
Olufunmilayo T. Ande1, Bola A. Senjobi² \\ ${ }^{1}$ Institute of Agricultural Research and Training, Obafemi Awolowo University, Ibadan, Nigeria \\ ${ }^{2}$ Federal University of Agriculture, Abeokuta, Nigeria \\ Email: funmiande@yahoo.com, senjobiba@funaab.edu.ng
}

Received 9 July 2014; revised 14 August 2014; accepted 22 September 2014

Copyright (C) 2014 by authors and Scientific Research Publishing Inc.

This work is licensed under the Creative Commons Attribution International License (CC BY). http://creativecommons.org/licenses/by/4.0/

(c) (†) Open Access

\begin{abstract}
The project was carried out to determine the effects of different fallow types on soil derived from sand stone of low nutrient status in south western Nigeria. The different fallow types include Leucaena, elephant grass, guinea grass and secondary forest. Cultivated farm land was used to serve as control for comparison of soil quality improvement. Soil samples were collected in four replicates on each land cover type and analyzed for major physical and chemical parameters. The results show little fertility improvement for base saturation with $1.42 \mathrm{cmol} / \mathrm{kg}$ in Leucaena, 1.99 $\mathrm{cmol} / \mathrm{kg}$ in secondary forest, $1.60 \mathrm{cmol} / \mathrm{kg}$ in guinea grass and in Elephant grass. Leucaena resulted to better soil quality than secondary forest especially in surface properties though not significantly different. Elephant grass and guinea grass also resulted to better Nitrogen content. Nitrogen content recorded in Leucaena was high with $0.20 \%-0.25 \%$. Guinea grass and elephant grass resulted to better soil quality in terms of nitrogen content $[0.20 \%-0.25 \%]$ than cultivated and secondary forest $[0.07 \%-0.11 \%]$ due to their yearly incorporation in to the soil by ploughing. The values of phosphorus were higher in Leucaena though not significant [6.46 mg/kg]. Low soil properties improvement is attributed to nutrient exploitation in Leucaena and secondary forest after a long period of fallow [20 years] while, nitrogen enrichment in the grasses is attributed to yearly tillage. Over all low to medium soil variability indicates that the soils could be managed as a unit for crop production.
\end{abstract}

\section{Keywords}

Soil Quality Improvement, Fallow Types, Improved Fallow, Leucaena 


\section{Introduction}

All over the world, it is now being recognized that the use of soil must be planned and that soil must be properly managed if it is to continue to support crops and give the maximum yield. A decrease in soil quality as measured by changes in soil properties, process and consequent decline in productivity in terms of immediate and future production is termed soil degradation. Soil degradation can also be termed as the physical and chemical deterioration of soil or reduction in soil quality in which it has major implication for agricultural productivity that is, they become less able to support plant and animal growth as there is a decline in levels of available moisture, available nutrients and biological activity [1].

One of the biological means of restoring degraded soils is by improved fallow. Such include planting of leguminous plant like Leucaena (Leucaena leococephala). It has been observed that erosion in plots with Leucaena Leucephala was reduced by $82 \%$ when compare to other control treatment [2]. Also reports have shown that yields of crop could be maintained for many years at reasonable levels with the use of Leucaena leucephala without application of inorganic fertilizers [3].

One of the most significant problems facing traditional farming system which the nation must solve is how to maintain soil fertility at a high productive level with increasing pressure and competition and yet eliminate the long bush fallow system.

At the outset of fallow different forms of weed are the first colonizers of land in the southern parts of Nigeria. It was reported that plants which have the ability to fix nitrogen are among the major plants in the fallow [4].

Three to four years after fallow, various species of herbaceous legumes start to appear, prominent among them is calopogonium mucunoides. This early colonizers are most tolerant of daily temperature fluctuations and water stress than the shrub legumes which appear much later. As the legumes get into the soil, nutrient status of the soil increases rapidly because the legumes fix more Nitrogen than they require [5].

The fallow period enables accumulations of organic matter and this depends on amount of humus contributed by the decaying litters and root residues. There is general reduction in the level of soil organic matter in the first three years of fallow [6]-[8]. Plant food materials normally lay locked up in the soil humus and underlying parent rocks. Given time and favourable conditions, these plants nutrients will return to the soil. The length of time piece of land be allowed to lie fallow depends on: stage of exhaustion of soil, system of crop rotation, quantity of land available for cropping year. Where land has been greatly over cropped, it is necessary to allow a long period of rest with plants such as Leuceana [9]. Where the system of crop rotation does not allow complete exhaustion of the soil, short periods of fallow could be allowed. In school farms, the fallow period is usually one or two years. With the use of a good leguminous fallow crop, one or two years fallow has been found adequate to maintain soil fertility. Recently attention is focused on improved fallow where easily decomposed plants rich in $\mathrm{N}$ are deliberately used as fallow [10]. Example of such is Leucaena leucocephela which is a perennial browse plant found growing in Nigeria. The young leaves are palatable and rich in protein on dry matter basis. It was observed that erosion in plots with Leucaena leucocephela was reduces by $83 \%$ when compare to the control treatment [2]. Moreover yields of crops could be maintained for many years at reasonable levels with the use of Leucaena leucocephala and application of inorganic fertilizers [10]. According to research findings, Leucaena luecocephala also provided favourable Microelements, which enhanced microfauna activities, thus enhancing soil water holding capacity and nutrient recycling which are beneficial to biological organism [11]. Soil with Leucaena leucocephala had high water retention capacity, high porosity and infiltration rate. This may be attributed to improved soil structure.

The potentials of grasses are also being explored for soil improvement. Example of such is elephant grass which is an indigenous drought resistant grass. It is a tall perennial grass growing to a height of $2-4$ metres. It has long penetrating root. It is one of the most valuable forage, silage and silage crops in the wet tropics. Elephant grass gives very effective control measure for erosion in its own ecological niche. It uptakes nutrients from the soil thereby prevent leaching. It helps in recycling soil nutrients. Research has also indicated the ability of leguminous tree like gliricidia (Gliricidia sepium) and Leucaena in improving soil quality [10].

Nutrient mining and soil degradation are usually considered as problems in arable farms especially on soils derived from sand stone in south western Nigeria [12]. The soils derived from sand stone are usually low in fertility and fragile and therefore need proper management to sustain and mitigate against degradation. Soils of Ikenne have been under various long term cultivation and land cover. The major land use/cover types include arable crops cultivation of (maize/cassava) more than 10 years, guinea grass (as pasture), elephant grass, sec- 
ondary forest and Leucaena for over ten years. The aim of this research is to assess the effects of improved fallow such as Leucaena on soil quality and to compare this with other land cover types and land uses in the area in order to guide soil quality improvement programmes on similar soils.

\section{The Study Area}

The soil samples for the study were collected at Institute of Agricultural Research and Training (I.A.R \& T) Research Station at Ikenne in Ogun State (Figure 1).

The climate of the area is between the humid and sub humid tropical, with an annual rainfall of $1436.3 \mathrm{~mm}$, with two peaks distribution pattern (June and September) and five dry months in the year. Mean temperature of the area is $26.3^{\circ} \mathrm{C}$ with February and March as the hottest months. The mean relative humidity is $75 \%$ while potential evapo-transpiration (PET) is $109 \mathrm{~mm}$. The major soils of the area were indentified as Alagba, Ibeshe and Agege at the upper and middle slopes respectively [13]. These have been classified as Oxic paleustults and Dystric Nitosols under USDA and FAO systems of classifications respectively [14].

\section{Land Use and Fallow Types}

Different land use types of varying fallow identified on the site include: guinea grass, secondary forest tree, elephant grass, Leucaena and land under continuous arable cultivation (maize/cassava) as control. The arable plot had been under cultivation with crops such as maize and cassava, for about 10 - 15 years. Fertility improvement was by addition of inorganic fertilizer every year. The guinea grass was established more than 15 years ago. The area had been constantly subjected to animal grazing such as cattle. The land was usually ploughed for cultivation but not cropped due to production constraint and hence reverted back to guinea grass. The secondary forest had been in existence for about 20 years. The secondary forest was characterized by canopies not fully formed with underground thickets, herbs and shrub. The elephant grass plot had been established for about 15 - 20 years. Since this was difficult to control, hence the practice was to plough it into the soil at the beginning of the planting season to avoid pest infestation and to avoid its encroachment on adjacent cultivated plot. The Leucaena trees plot had been established for about 15 years. They were planted with spacing of $5 \mathrm{~m}$ by $5 \mathrm{~m}$ as fallow plants to improve the fertility.

\section{Field Work}

The layouts of the different fallow types were shown in Figure 1. Each area represented by the fallow types/land use type were divided into four and samples were randomly collected from each of the polygon demarcated for the land use/cover types. The soil samples were taken systematically at $0-30 \mathrm{~cm}$ and $30-60 \mathrm{~cm}$. Mini-pits were dug at the sampling points for sub surface sampling to avoid contamination. Core sampler was used to collect samples for bulk density determination.

\section{Laboratory Analytical Methods}

The soil samples were air dried, grounded and sieved by $2 \mathrm{~mm}$ sieve. Samples were further sieved through 0.5 $\mathrm{mm}$ for organic carbon and nitrogen determination before subjected to laboratory analysis. They were processed for chemical and physical analysis of the fine earth $(<2 \mathrm{~mm})$ fraction with the standard analysis method [15]. The gravel contents $2 \mathrm{~mm}$ were weighed and recorded.

Particle size analysis was carried out using hydrometer method [16] using sodium hexametaphosphate as the dispersing agent. The $\mathrm{pH}$ of the samples was measured in soil-water suspension (1:1 in water) electrometrically using the glass electrode $\mathrm{pH}$ meter after 30 minutes of equilibration. Soil organic carbon was determined using digestion method [17]. The method involved wet-oxidation procedure and back titration to measure the amount of unreacted dichromate.

Exchangeable acidity $\left(\mathrm{AI}^{3+}\right)$ was extracted with 1.0M KCI and titrated with ammonium acetate. Exchangeable bases were extracted with I.OM ammonium acetate $\left(\mathrm{NH}_{4} \mathrm{OAC}\right)$ at $\mathrm{pH} 7 . \mathrm{Ca}^{2+}$ and $\mathrm{Mg}^{2+}$ in the soil were determined with atomic absorption spectrophotometer while $\mathrm{K}^{+}$and $\mathrm{Na}^{+}$were determined with flame photometer. Cation Exchangeable Capacity (ECEC) was obtained by summation of exchangeable bases. Available phosphorus was extracted by Bray-1 extractant [18] of $0.03 \mathrm{~N} \mathrm{NH}_{4} \mathrm{~F}$ in $0.025 \mathrm{~N}$ HCL. The base saturation was calculated as ratio of exchangeable bases to the cation exchange capacity express in percentage. Bulk density was determined 


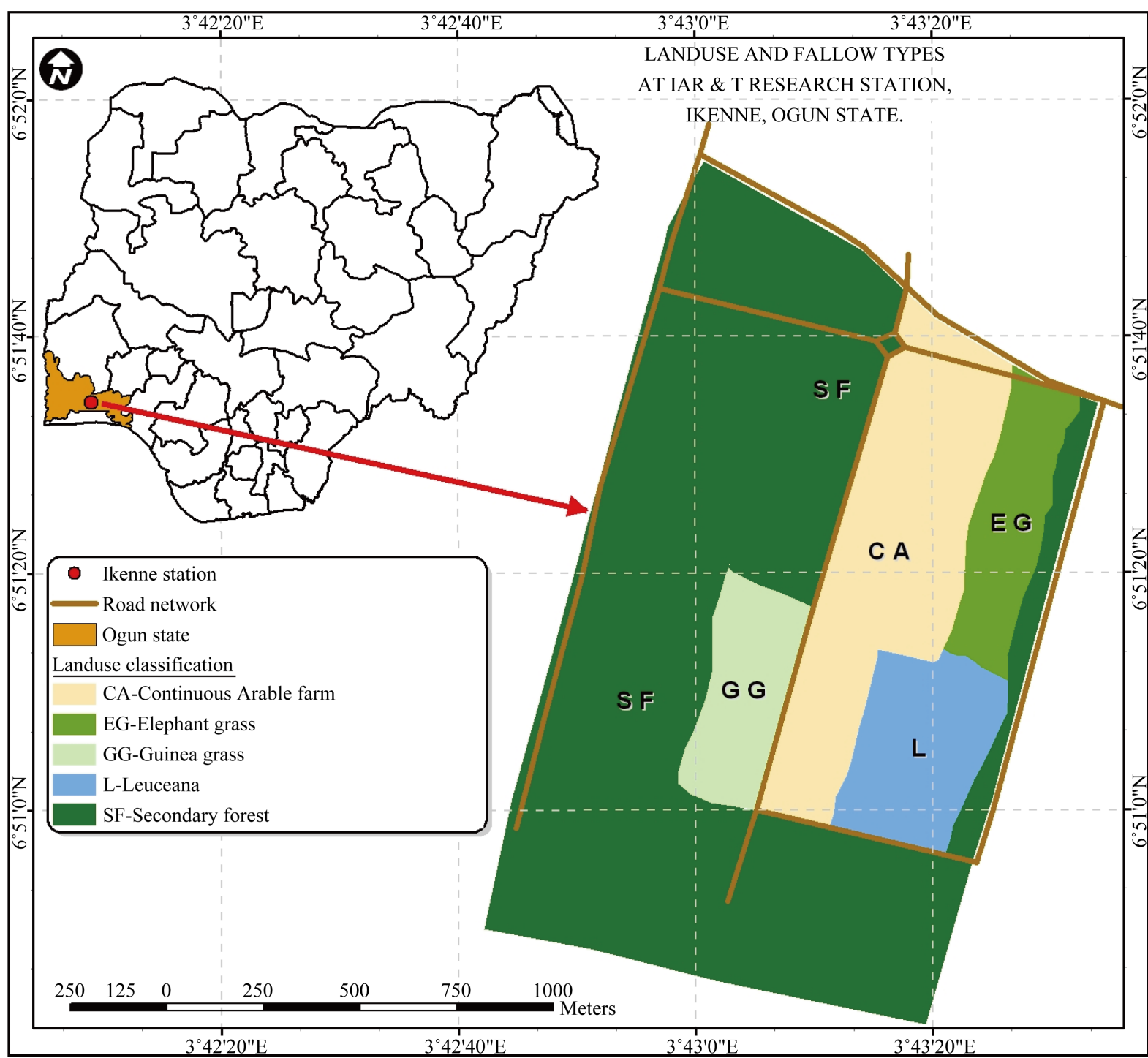

\begin{tabular}{|c|c|c|}
\hline SN & NAME & AREA (Ha) \\
\hline 1 & CA-Continuous Arable farm & 37.88 \\
\hline 2 & EG-Elephant grass & 12.89 \\
\hline 3 & GG-Guinea grass & 12.66 \\
\hline 4 & L-Leuceana & 16.20 \\
\hline 5 & SF-Secondary forest & 142.54 \\
\hline
\end{tabular}

Figure 1. Fallow and land use types of the study area.

using core sample method which is calculated by dividing the mass of the soil by volume of the soil. Porosity was calculated using the relationship (1-BD) X100/PD, where BD is bulk density; PD is Particle density with a value of $2.65 \mathrm{~g} / \mathrm{cm}^{2}$ for mineral soils. Hydraulic conductivity was determined by constant head method. This procedure allows water to move through the soil under a steady state head condition while the quantity (volume) of water flowing through the soil specimen is measured over a period of time. The hydraulic conductivity was calculated by the quantity $\mathrm{Q}$ of water measured, length $\mathrm{L}$ of specimen, cross-sectional area $\mathrm{A}$ of the specimen, time $t$ required for the quantity of water $\mathrm{Q}$ to be discharged, and head $\mathrm{h}$. The results were subjected to analysis of variance to know the effect of different fallow types on soil properties/quality and the means were separated 
with the New Duncan Multiple Range Test (DMRT) at $\mathrm{p}<0.05$.

\section{Results}

Table 1 and Table 2 showed the physical and chemical properties of the top soils from the different fallow types/land uses. The highest mean for clay content (15.48\%) was recorded in cultivated land but was not significantly different $(\mathrm{p}<0.05)$ from others and it has highest sand content $(71 \%)$ as well.

The lowest bulk density $\left(0.84 \mathrm{~g} / \mathrm{cm}^{3}\right)$ was recorded on the secondary forest soil followed by $0.87 \mathrm{~g} / \mathrm{cm}^{3}$ in Leucaena. The higher bulk density in cultivated plot and elephant grass could be attributed to effect of mechanisation and trampling of livestock respectively.

The chemical analyses show that $\mathrm{pH}$ varies from 5.48 to 5.13 but are not significantly different at $\mathrm{p}<0.05$. Available phosphorus was higher under elephant grass and Leucaena. The higher availability of phosphorus in the cultivated plot could be attributed to application of inorganic fertilizer (NPK). Highest content of Carbon (2.44\%) and Nitrogen were recorded in both elephant grass and Leucaena plots and this could be attributed to yearly tillage of the plot thereby increasing the biomass. The operation was usually done to avoid pest and further infestation on adjacent arable land. The $\mathrm{N}$ contents in Leucaena, elephant grass and guinea grass were higher and significantly different from cultivated and secondary forest.

Potassium and calcium were low in all the land cover types, but were higher in cultivated and in secondary forest plots. This could be due to application of fertilizer and nutrient recycling respectively. Sodium content varies between 0.10 to $1.23 \mathrm{cmol} / \mathrm{kg}$ with lowest value in cultivated soil and highest in Leucaena. The lowest value $0.1 \mathrm{cmol} / \mathrm{kg}$ recorded under cultivated could be attributed to ease of leaching after soils are cleared for production and high mobility of sodium in soils. Magnesium was significantly different in all the land cover with maximum reading of $0.25 \mathrm{cmol} / \mathrm{kg}$ under cultivated soil which could be due to fertilizer application and lowest reading $0.70 \mathrm{cmol} / \mathrm{kg}$ under secondary forest. The type of vegetation also affects mineralisation and release of nutrient.

Table 3 and Table 4 showed the physical and chemical properties in the sub soils of the land use types. In the subsoil, the clay contents increased and more clay was recorded for arable plot. The soil properties were significantly different with Leucaena, elephant grass and guinea grass having comparable performance in terms of \% C and $\% \mathrm{~N}$. Available $\mathrm{p}$ was also higher under Leucaena, guinea grass and elephant grass than in secondary forest.

Table 1. Differences in soil physical properties in the surface soil $(0-30 \mathrm{~cm})$.

\begin{tabular}{ccccccc}
\hline Soil property & Cultivated & Elephant grass & Guinea grass & Leucaena & Secondary forest & C V \% \\
\hline Sand & 71.14 & $68.78^{\mathrm{a}}$ & $67.76^{\mathrm{a}}$ & $62.78^{\mathrm{a}}$ & $57.78 \mathrm{~b}$ & 9.76 \\
Clay & $15.48^{\mathrm{b}}$ & $12.48^{\mathrm{a}}$ & $12.48^{\mathrm{a}}$ & $13.75^{\mathrm{a}}$ & $14.75^{\mathrm{a}}$ & 12.16 \\
Silt & $13.38^{\mathrm{b}}$ & $16.7^{\mathrm{b}}$ & $19.74^{\mathrm{ab}}$ & $23.47^{\mathrm{a}}$ & $27.47^{\mathrm{a}}$ & 28.46 \\
BD & $0.95^{\mathrm{b}}$ & $0.96^{\mathrm{b}}$ & $0.92^{\mathrm{b}}$ & $0.87^{\mathrm{a}}$ & $0.84^{\mathrm{a}}$ & 6.23 \\
\hline
\end{tabular}

Mean with the same letter are not significantly different from each other $(\mathrm{p}<0.05)$.

Table 2. Differences in soil chemical properties in the surface soil $(0-30 \mathrm{~cm})$.

\begin{tabular}{|c|c|c|c|c|c|c|}
\hline Soil property & Cultivated & Elephant grass & Guinea grass & Leucaena & Secondary forest & $\mathrm{CV} \%$ \\
\hline $\mathrm{PH}(\mathrm{H} 20)$ & $5.13^{\mathrm{a}}$ & $5.28^{\mathrm{a}}$ & $5.28^{\mathrm{a}}$ & $5.48^{\mathrm{a}}$ & $5.43^{\mathrm{a}}$ & 4.65 \\
\hline A.V.P (mg/kg) & $4.79^{b}$ & $6.7^{\mathrm{a}}$ & $2.87^{\mathrm{b}}$ & $6.46^{\mathrm{a}}$ & $3.35^{b}$ & 24.15 \\
\hline Carbon\% & $0.86^{\mathrm{b}}$ & $2.44^{\mathrm{a}}$ & $2.35^{\mathrm{a}}$ & $2.44^{\mathrm{a}}$ & $0.69^{\mathrm{b}}$ & 28.98 \\
\hline Total N \% & $0.08^{\mathrm{b}}$ & $0.25^{\mathrm{a}}$ & $0.24^{\mathrm{a}}$ & $0.25^{\mathrm{a}}$ & $0.07^{\mathrm{b}}$ & 26.16 \\
\hline $\mathrm{K}(\mathrm{cmol} / \mathrm{kg})$ & $0.42^{\mathrm{a}}$ & $0.25^{\mathrm{b}}$ & $0.35^{\mathrm{ab}}$ & $0.42^{\mathrm{a}}$ & $0.28^{\mathrm{b}}$ & 21.42 \\
\hline $\mathrm{Na}(\mathrm{cmol} / \mathrm{kg})$ & $0.10^{\mathrm{b}}$ & $0.10^{\mathrm{b}}$ & $0.29^{\mathrm{b}}$ & $1.23^{\mathrm{a}}$ & $0.69^{\mathrm{ab}}$ & 13.39 \\
\hline $\mathrm{Ca}(\mathrm{cmol} / \mathrm{kg})$ & $1.92^{\mathrm{a}}$ & $1.04^{\mathrm{ab}}$ & $0.87^{\mathrm{b}}$ & $0.68^{\mathrm{b}}$ & $0.76^{\mathrm{b}}$ & 21.53 \\
\hline $\mathrm{Mg}(\mathrm{cmol} / \mathrm{kg})$ & $0.25^{\mathrm{a}}$ & $0.20^{\mathrm{a}}$ & $0.12^{\mathrm{b}}$ & $0.14^{\mathrm{b}}$ & $0.07^{\mathrm{b}}$ & 18.28 \\
\hline CEC (cmol/kg) & 2.69 & 1.63 & 1.63 & 2.47 & 1.80 & \\
\hline
\end{tabular}

Mean with the same letter are not significantly different from each other $(p<0.05)$. 
Table 3. Differences in soil physical properties among fallow type sub soil (30 - $60 \mathrm{~cm})$.

\begin{tabular}{ccccccc}
\hline Soil property & Cultivated & Elephant grass & Guinea grass & Leucaena & Secondary forest & C.V \% \\
\hline Sand \% & $52.27^{\mathrm{a}}$ & $50.78^{\mathrm{a}}$ & $44.23^{\mathrm{a}}$ & $54.73^{\mathrm{a}}$ & $45.28^{\mathrm{a}}$ & 1333 \\
Clay \% & $34.48^{\mathrm{a}}$ & $32.48^{\mathrm{a}}$ & $31.48^{\mathrm{a}}$ & $25.75^{\mathrm{b}}$ & $24.78^{\mathrm{b}}$ & 23.78 \\
Silt \% & $13.38^{\mathrm{b}}$ & $16.74^{\mathrm{b}}$ & $24.29^{\mathrm{a}}$ & $19.25^{\mathrm{ab}}$ & $29.95^{\mathrm{a}}$ & 31.12 \\
B.D $\left(\mathrm{g} / \mathrm{cm}^{3}\right)$ & $0.94^{\mathrm{a}}$ & $0.96^{\mathrm{a}}$ & $0.90^{\mathrm{a}}$ & $0.84^{\mathrm{b}}$ & $0.84^{\mathrm{b}}$ & 6.23 \\
\hline
\end{tabular}

Mean with the same letter are not significantly different from each other $(\mathrm{p}<0.05)$.

Table 4. Differences in soil chemical properties among fallow type sub soil $(30-60 \mathrm{~cm})$.

\begin{tabular}{ccccccc}
\hline Soil property & Cultivated & Elephant grass & Guinea grass & Leucaena & Secondary Forest & C V \% \\
\hline $\mathrm{PH}\left(\mathrm{H}_{2} \mathrm{O}\right)$ & $5.33^{\mathrm{ab}}$ & $5.45^{\mathrm{a}}$ & $5.28^{\mathrm{ab}}$ & $5.28^{\mathrm{ab}}$ & $5.05^{\mathrm{ab}}$ & 3.10 \\
A.V.P (mg/kg) & $2.39^{\mathrm{c}}$ & $4.31^{\mathrm{a}}$ & $2.87^{\mathrm{c}}$ & $3.11^{\mathrm{b}}$ & $2.16^{\mathrm{c}}$ & 23.88 \\
$\mathrm{Carbon} \%$ & $0.61^{\mathrm{c}}$ & $1.70^{\mathrm{a}}$ & $1.50^{\mathrm{a}}$ & $1.96^{\mathrm{a}}$ & $1.04^{\mathrm{b}}$ & 28.12 \\
Total N \% & $0.11^{\mathrm{b}}$ & $0.17^{\mathrm{a}}$ & $0.15^{\mathrm{a}}$ & $0.20^{\mathrm{a}}$ & $0.11^{\mathrm{b}}$ & 24.40 \\
$\mathrm{~K} \mathrm{cmol} / \mathrm{kg}$ & $0.60^{\mathrm{a}}$ & $0.83^{\mathrm{a}}$ & $0.24^{\mathrm{b}}$ & $0.21^{\mathrm{b}}$ & $0.21^{\mathrm{b}}$ & 29.31 \\
$\mathrm{Na}(\mathrm{cmol} / \mathrm{kg})$ & $0.12^{\mathrm{b}}$ & $0.09^{\mathrm{b}}$ & $0.34^{\mathrm{a}}$ & $0.44^{\mathrm{a}}$ & $0.90^{\mathrm{a}}$ & 14.48 \\
$\mathrm{Ca}(\mathrm{cmol} / \mathrm{kg})$ & $1.67^{\mathrm{a}}$ & $1.04^{\mathrm{ab}}$ & $0.87^{\mathrm{b}}$ & $0.68^{\mathrm{b}}$ & $0.76^{\mathrm{b}}$ & 21.53 \\
$\mathrm{Mg}(\mathrm{cmol} / \mathrm{kg})$ & $0.25^{\mathrm{a}}$ & $0.20^{\mathrm{a}}$ & $0.15^{\mathrm{ab}}$ & $0.09^{\mathrm{b}}$ & $0.12^{\mathrm{ab}}$ & 27.08 \\
$\mathrm{CEC} \mathrm{(cmol} / \mathrm{kg})$ & 2.64 & 2.16 & 1.60 & 1.42 & 1.99 & \\
\hline
\end{tabular}

Mean with the same letter are not significantly different from each other $(\mathrm{p}<0.05)$.

This shows the potential of grass to improve soil $\mathrm{P}$ when incorporated to soil.

The chemical parameters decrease in the sub soil except CEC. The CEC was generally low but higher under arable than other plots The CEC increased in the sub soil under forest compare to Leucaena which indicates better nutrient recycling. The increase of CEC under arable could be attributed to leaching when the soils are cleared before crops cover the ground effectively. The variability of soil properties was low to medium generally. Silt was most variable in the surface and sub soils while $\mathrm{K}$ was most variable chemical parameter.

\section{Discussion}

The commonest feature of traditional farming in Nigeria is the growing of different crop species simultaneously on the same piece of land with continuous cropping; the soil deteriorated because of the heavy rainfall on open and cleared cultivated lands which lead to severe erosion. Repeated removal of arable crops with little opportunity for soil recuperation render inevitable a heavy drain on the soil nutrient supply which intensifies the loss of organic matter and deterioration of physical condition. As the land is continuously cultivated with manuring or fertilization, yield usually declines [9] [19]. The comparable CEC with other fallow crop could be attributed to effects of yearly fertilization. However the yearly mechanisation has led to increased bulk density in arable plot compared with Leucaena and secondary forest plots.

Under secondary forest the soil secured and renewed the forest, just like the forest helped to secure and renew the soil. The forest covered and protected the soil from extreme heat and cold while slowing the nature forces of erosion like water, wind and gravity. However the improvement of soil quality depends on type of vegetation that dominates the area. The vegetation was mainly creepers with leaves and stolon that could not easily decomposed. This could explain the low nutrient built up under the forest. Moreover the soil of the area was inherently low in nutrient. The plot under guinea grass was usually left for grazing animals and this could explain the comparable bulk density and \% carbon with elephant grass. Grazing animal exert pressure on the ground comparable to that of agricultural machinery. As a result, soil under pasture could be compacted, also decrease in micro and macro pores occurred as well as destruction of soil structure. The yearly tillage of elephant grass plot and bush burning in the guinea grass plots coupled with grazing could explain the comparable results in \% C with Leucaena.

Overall low soil quality improvement was attributed to nutrient exploitation in Leucaena (about 15 years) af- 
ter long period of fallow. In secondary forest, the type of vegetation and inherent low fertility are considered to be responsible. While nitrogen enrichment in grasses was attributed to yearly tillage thus adding biomass to the soil but were poor in other soil parameters measured except elephant grass plot with higher P comparable to that recorded for Leucaena. This finding was in line with past findings that leguminous tree contributed high improvement to soil quality better than secondary forest [10]. It seems that exploitation replaces amelioration with leguminous tree after long fallow. Moreover these results indicate that grasses can improve soil biomass, organic carbon and nitrogen if ploughed to serve as compost. The low to medium variability of soil properties could be attributed to the binding effects of plant roots on the soils, while K with highest CV (29\%) for chemical parameters could be attributed to its high mobility in soil. Over all low to medium soil variability indicates that the soils could be managed as a unit for crop production (average for surface/sub soil chemical 19.72\% and 21.46\% respectively).

\section{Conclusion and Recommendation}

The study was conducted to carry out effects of different fallow types on soil properties. The different land covers resulted to different soil qualities. Leucaena was best in terms of soil quality. It improves soil quality better than secondary forest in eight parameters ${ }_{\mathrm{p}} \mathrm{H}$, Av. P, Percent carbon, total nitrogen, potassium, sodium, calcium and magnesium), however, higher calcium and magnesium recorded on cultivated soil could be attributed to fertilizer application.

\section{Acknowledgements}

The management of Institute of Agricultural Research and Training, Obafemi Awolowo University, Ibadan is hereby acknowledged for providing fund and facilities for the research.

\section{References}

[1] Ernst, D.T. (1995) The Farmer's Earthworm Handbook: Managing Your Underground Money Makers. Lessiter Publications, Brookfield, $112 \mathrm{p}$.

[2] Arowolo, A.D. (2007) Alley Farming and Sustainable Agriculture. Proceedings of Annual Conference of IRDI Research and Development Network, 2, 44-48.

[3] Kang, B.T. and Mulongoy, K. (1992) Nitrogen Contribution of Woody Legumes in Alley Cropping Systems. In: Mulonogy, K., Gueye, M. and Spencer, D.S.C., Eds., Biological Nitrogen Fixation and Sustainability of Tropical Agriculture, Wiley, Hoboken, 367-375.

[4] Agboola, D.A. (1991) The Effects of Soil Types and pH on the Germination of Seeds of Some Tropical Forest Tree Species. 5th Annual Conference of the Botanical Society of Nigeria, Ile-Ife, 24-28 March 1991, 20-37.

[5] Agboola, A.A. and Unamma, P.A. (1991) Maintenance of Soil Fertility under Traditional Farming System. Proceedings of the National Organic Fertilizer Seminar held in Kaduna, Abuja, 12-16 September 1991, 7-20.

[6] Aweto, A.O. (1981) Secondary Succession and Soil Fertility Restoration in South-Western Nigeria. I. Succession. Journal of Ecology, 69, 601-607. http://dx.doi.org/10.2307/2259686

[7] Aweto, A.O (1981) Secondary Succession and Soil Fertility Restoration in South-Western Nigeria. II. Soil Fertility Restoration. Journal of Ecology, 69, 609-614. http://dx.doi.org/10.2307/2259687

[8] Agboola, D.A. (1998) The Effect of Saline Solution and Salt Stress on the Germination of Seeds of Some Tropical Forest Tree Species. Revista de Biologia Tropical, 46, 1107-1113.

[9] Attah-Krah, A.N. (1990) Alley farming with Leucaena: Effect of Short Grazed Fallows on Soil Fertility and Crop Yields. Experimental Agriculture, 26, 1-10. http://dx.doi.org/10.1017/S0014479700015349

[10] Ande, O.T. and Onajobi, J. (2008) Assessment of Effects of Controlled Land Use Types on Soil Quality Using Inferential Method. African Journal of Biotechnology, 8, 6267-6271.

[11] Magdoff, F. and Harold, E. (2000) Building Soils for Better Crops. Sustainable Agriculture Network, 2005.

[12] Ande, O.T., Adediran, J.A., Ayoola, O.T. and Akinlosolu, T.A. (2008) Effects of Land Quality, Management and Cropping Systems on Cassava Production in South-Western Nigeria. African Journal of Biotechnology, 17, 2368-2374.

[13] Murdoch, G., Atere, J.O., Colborne, G., Olomu, E.I. and Odugbesan E.M. (1976) Soils of the Western State Savanna in Nigeria. Land Resources Div., Ministry of Overseas Development, Tolworth, Surbitton, Surrey, 3-11

[14] Nwanchokor, M.A. and Nzu, F.O. (2008) Updated Classification of Some Soils Series in South Western Nigeria. Jour- 
nal of Agronomy, 7, 76-81. http://dx.doi.org/10.3923/ja.2008.76.81

[15] International Institute of Tropical Agriculture: IITA (1979) Selected Methods for Soil and Plant Analysis. Manual Series No. 1, 3rd Edition, IITA, Ibadan, 34.

[16] Bouyoucous, G.J. (1951) A Recalibration of the Hydrometer for Making Mechanical Analysis of Soils. Agronomy Journal, 43, 434-438. http://dx.doi.org/10.2134/agronj1951.00021962004300090005x

[17] Walkey, A. and Black, I.A. (1934) An Examination of the Degtajareff Method for Derterming Organic Matter and a Proposed Modification of the Chromic and Acid Titration.

[18] Bray, R.N. and Kurtz, L.T. (1945) Determination of the Organic and Available Forms of Phosphorus in Soil. Soil Science, 59, 39-45. http://dx.doi.org/10.1097/00010694-194501000-00006

[19] Attah-Krah, A.N. and Okali, D.U. (1986) Report of Advisory Group Meeting on Use of Nuclear Techniques in Studying Roles of Trees in Restoring and Maintaining Soil Fertility. IAEA, Vienna, 40. 
Scientific Research Publishing (SCIRP) is one of the largest Open Access journal publishers. It is currently publishing more than 200 open access, online, peer-reviewed journals covering a wide range of academic disciplines. SCIRP serves the worldwide academic communities and contributes to the progress and application of science with its publication.

Other selected journals from SCIRP are listed as below. Submit your manuscript to us via either submit@scirp.org or Online Submission Portal.
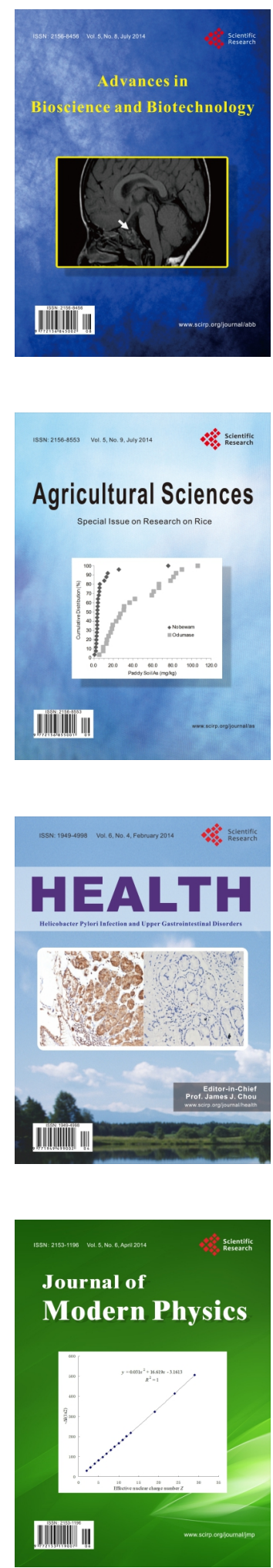
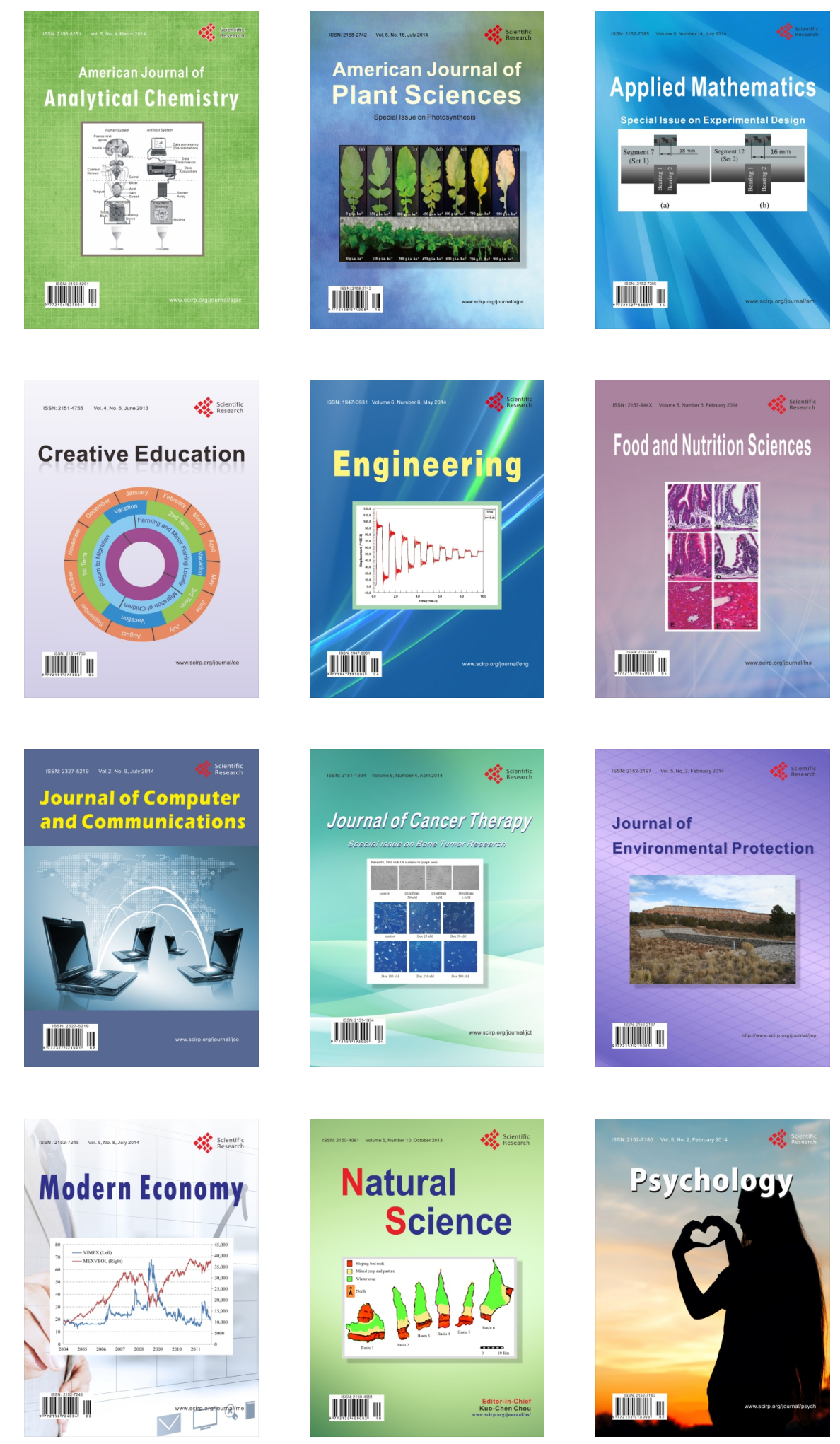